\title{
Differences in Information Technology Systems in Public and Private Sector
}

\author{
Marwah Yusuf, Paulus Tangke, Grace T. Pontoh \\ Hasanuddin University, Indonesia \\ gpontoh@yahoo.com
}

\begin{abstract}
This study aims to examine differences in information technology acceptance in the public sector and private sector in Indonesia. This study explores previous research on the subject, especially with regard to the Technology Acceptance Model (TAM). Acceptance of technology according to theory can be influenced by several aspects, such as: behavior, satisfaction, benefits, convenience, social as well as security and privacy. Of the various aspects of this most influential generally considered to differences in acceptance of the technology on "every individual" in the public sector and the private sector there are two namely: aspects of behavior and benefits.
\end{abstract}

Keywords: Information Technology systems, public sector, private sector

\section{Introduction}

The public sector and the private sector are the two sectors of activity within the community. These two sectors have different characteristics in their activities. Public sector activities more on service to the public interest, while the private sector with the activity of providing products and services to meet community needs to take into account the profit from such activities. In other words the public sector is not profit-oriented while the private sector is profit-oriented. Given the different characteristics of the public sector and the private sector, operationally also appears to differ mainly in its services. The private sectorfor profit-oriented (profit maximization) will strive to excel in competition with competitors, Farlan (1983) and Rockart (1998) in Rahadi (2007), on the other hand the public sector non-profit and governmentsupervised less or even not feel any pressure from the competition and the owner so do not prioritize the delivery of public services. This has an impact on the services of the two sectors that are very much different in quality of service. One of the factors that distinguish the quality of service in the public sector with the private sector is the acceptance of information technology in the activities of both sectors. The private sector or the private sector will be very quick to respond and to follow and implement the information technology system than the public sector because of the demands to be able to compete with its rivals. On the other hand the public sector with its status as a government agency seems less or is slow to respond and follow perkemban gan information technology systems. Less or lambatanya government attention on the development and acceptance of technology may be caused by cost factors, and the ability of Human Resources (HR) including officials at each agency may be less understanding of information technology systems so less interested in the acceptance of new technology. Rahadi (2007) explains that one of the factors that influence the different characteristics of IT users is the aspect of behavior. Behavior will beinfluenced by the user's perception of the IT theoretically described by the experts of IT as a user and its influence on the use of computers (Davis et al., 1989). The aspect of user's keprilakuan (user) also influences perception and attitude in receiving IT usage. Behavior can be demonstrated by the government in adopting the immature state of IT in improving services to the community as well as promoting transparency and accountability (Rahadi, 2007). This literature study wanted to examine and determine the factors that influence differences in acceptance of information technology systems in the public sector and the private sector based literatureliterature from earlier studies.

\section{Literature Review}

The development of information technology (IT) is currently very very rapid. This provides many benefits and services on various aspects of activities both in the private sector and the public sector.But the question for us today is why services in the private sector are generally relatively faster and better than in the public sector? Researchers have been conducting research to study the process of integration of information systems and technology since the 1970s and several models have been developed to help analyze and understand the factors that affect the acceptance of the use of technology - especially computer technology, 
including those recorded in some literature and reference results research in information technology, such as the Theory of Reasoned Action (TRA) by Icek Ajzen and Martin Fishbein (1980), Theory of Planned Behavior (TPB) by Ajzen, (1988) and the technology Acceptance Model (TAM) by Fred D. Davis (1986). Technolog y Acceptance Model (TAM)) is one model the use of information technology systems that are considered very influential and is commonly used to describe the individual acceptance of the use of information technology systems for this model is considered to be simpler and easier to implement, Wijayanti (2009). TAM is the result of the development of Theory of Reasoned Action (TRA).TAM adds two major constructs into the model TRA, the user's perception of the benefits (perceived usefulness) and the user's perception of the ease (Jogiyanto, 2008). The user's perception of the benefits (perceived usefulness) is the perception in which a person believes that using a particular system can improve its performance, while the user's perception of the ease is the perception in which a person believes that using the system will not need any effort (free of effort), the user's perception of the ease too effect on the user's perception of the benefits (perceived usefulness)which can be interpreted that if a person feels easy in use a system, the system will be useful to them (Wijayanti, 2009).

\section{Discussion}

From some literature and reference previous research pointed out that there are several factors that affect individuals in receipt of technology, among others, aspects of behavior, satisfaction aspects, aspects of convenience and benefits and aspects of security and privacy aspects.

Aspect of Behavior: Man as a psychological system users have a behavior (behavior) that certain attached to him, so that aspect keprilakuan in the human context as users of information technology (brain-ware - IT) becomes important as a deciding factor in everyone who runs IT. Behavioral considerations need to be given special attention in the context of the acceptance of information technology (IT). Thompson et al. (1991) in Rahadi (2007) describes the attitude factor (attitude) as one of the aspects that influence individual behavior in which a person's attitude consisting of components of cognition (cognitive), affective (affective) And components related to the behavior (behavioral components).

Aspects of Satisfaction: Individual and collective acceptance of the use of information technology systems can be explained by variations in the use of a system as it is believed that the use of a system based on information technology (IT) can develop individual performance or the performance of the organization (Iqbaria, 1994; Luthans, 1995 and Nelson, 1996 in Rahadi, 2007). Aspects of user satisfaction has been identified on several other studies as one of the factors acceptance of IT, which is generally known that the acceptance of information technology (IT) can be seen from the use of the system and the frequency of the use of IT and some are viewed from the aspect of user satisfaction (DeLone, 1981; Soh et al., 1992; Montazemi, 1988; Raymond, 1985,1990; Iqbaria et al., 1997 in Rahadi, 2007).

Aspects of Benefits: As we know that s ne of the k onstr uk on the Technology Acceptance Model (TAM) is the perception of the usefulness (perceived usefulness) which is defined as the extent to which a person believes that the use of a technology will improve the performance of his work ("as the extent to the which a person Believes that using a technology will Enhance his or her performance "), (Jogiyanto, 2008). This definition is similar to the definition put forward by Davis et al. (1989) and Adam et al. (1992) in Rahadi (2007) that efficacy (usefulness) is a degree to which a person believes that the use of a specific technology subjects will be able to improve the work performance of the person. Thus from this definition can be interpreted that the expediency of the use of information technology (IT) can improve performance, achievements working people who use it. Utilization of information technology is a benefit expected by IT users in performing tasks and work. Measurement of usefulness can be done based on the frequency of use and diversity / diversity of applications run. Chin and Todd (1995) in Rahadi (2007) provide several dimensions of the usefulness of information technology and classify it in two categories:

- Utilization with one factor estimate, including dimensions:
a. make the job easier (makes job Easier)
b. useful (useful)
c. add productivity (increase of productivity)
d. enhance the effectiveness (enchance efectiveness) 
e. develop job performance (improve job performance)

- Utilization with two factor estimate, consisting of:

- Utilization includes dimensions:

a. make the job easier (makes job Easier)

b. useful (useful)

c. increases productivity (increase of productivity)

- Effectiveness includes dimensions:

d. enhance the effectiveness (enchance efectiveness)

e. developing the job performance (improve job performance)

Aspect of Convenience: Aspects of ease is a construct of the second additional on TAM which is defined as the extent to which a person believes that using a technology would be free of effort ("is the extent to the which a person Believes that using a technology will be free of effort"), (Jogiyanto, 2007). Aspects of expediency by Davis et al. (1989) in Zahid et al. (2010) defined as so far where someone believe that use system certain will improve performance job. People adapt with technology certain because it considers that use technology and System information will improve performance them. The more frequently used systems show that the system is better known, easier to operate and easier to use by its users.

Social Aspects: The social aspect or social norms may affect the person's behavior in which a person will be affected by the news received from others and reflect on what people think should be done for, Triandis (1971) in Jogiyanto, (2008). Social factors as the individual's internalization of subjective reference group culture, and specific interpersonal agreements that have been made by the individual with others in certain social situations. IT in the literature to date, the role of subjective norms as determinants of use T I somewhat unclear. Good Davis et al. (1989) and Mathieson (1991) found no significant relationship between subjective norms and intentions. However, research in organizational settings have found subjective norms become important determinants of intention or the use of T I (Hartwick and Barki, 1994).

Security and Privacy Aspects: Aspects of security and privacy is one factor consideration of acceptance of information technology system. From a security standpoint technology users will feel more secure and also from aspects of user privacy privacinya also feel more secure. Security and privacy have effect directly and significant to trust consumers, users and the public. When people have confidence and guarantee about privacy and security then of course that will push them to use information technology which would maintain security and privacy. Problem security is wrong one the most important obstacle for reception technology information system (Laforet and Li, 2005). Manzano et al. (2008) states that the perceived risk composed of security, privacy, performance and factors social, and have a strong bearing in adopting information technology systems.

\section{Differences in Reception of Technology Information Systems in the Public Sector}

Private Sector: Based on the description of some of the aspects that affect the acceptance of information technology systems above it was explained that the main reason for the private sector is superior in the acceptance of information technology systems is a factor of competition, and the attempt to reduce operating costs as efficiently as possible to encourage the private sector to take advantage of the system informarsi technology in run its activities. Increasing mobility rates in the community have led to private or private sector service providers having to make innovations in their products or services with the acceptance of technology as part of innovation. On the other hand the public sector with its status as a government agency is strongly bound by the regulation of the central government. Besides the public sector there is no pressure of competition with other parties as competitors so they are not so challenged by innovation to improve its service to the community. And more importantly, individual performance appraisals take precedence over the private sector rather than the public sector so that the Human Resources (HR) in the public sector appears to be less rapid in responding to the development and acceptance of technology. In other words, human resources in the private sector will make every effort to demonstrate achievement through performance for career improvement or at least to maintain the "fate" of his; different from the human resources in the public sector who might feel "safer position" because it is protected by the rules and performance assessment is less noticed by the boss or the office. 


\section{Conclusion}

Technology has become a major driver which brings change and makes things easier in a timely manner. Technological breakthroughs have brought huge changes especially from the last century. But technological breakthroughs indicate acceptance of different individuals in the private sector or private individuals in the public sector. Technology Acceptance Model (TAM) is specifically constructed to determine the factors that influence a person to accept the technology and information systems. TAM has two key factors, namely the perceived ease of use and perceived usefulness as a major factor to one's intention to receive and use information technology (IT). Variation in information technology in the private sector with the public sector is the motivation of individuals higher in the private sector, emphasis on more stringent performance measures on private or private sectors, and more flexible but less "secure" private sector HR status than in the public sector. In other words, the difference in the acceptance of information technology for each individual in the private and public sectors in general lies in aspects of behavior and benefits aspects.

\section{References}

Davis, F. D., Bagozzi, R. P. \& Warshaw, P. R. (1989). User acceptance of computer technology: a comparison of two theoretical models. Management Science, 35(8), 982-1003.

Hartwick, J. \& Barki, H. (1994). Explaining the role user participation in information system use. Management Science, 40, 440-465.

Jogiyanto. (2008). Sistem Informasi Keperilakuan, EdisiRevisi CV. Andi Offset.

Laforet, S. \& Li, X. (2005). Consumers' attitudes towards online and Mobilebanking in China. International Journal of Bank Marketing, 23(5), 362-380.

Manzano, J. A., Navarre, C. L., Mafe, C. R. \& Sanz-Blas, S. (2009). Key drivers of Internet banking services use. Online Information Review, 33(4), 672-695.

Mathieson, K. (1991). Predicting intentions: Comparing the technology acceptance model with the theory of planned behavior. Information Systems Research, 2, 173- 191.

Rahadi, D. R. (2007). Peranan Teknologi Informasi dalam Peningkatan Pelayanan di Sektor Publik, Seminar Nasional Teknologi (SNT, 2007), Yogyakarta.

Wijayanti, R. (2009). Analisis Technology Acceptance Model (TAM) Terhadap Faktor-Yang Mempengaruhi Penerimaan Nasabah Terhadap Layanan Internet Banking; Jurusan Akuntansi, Fakultas Ekonomi Universitas Gunadarma, Depok - Jakarta.

Yousafzai, S. Y., Gordon, R., Oxall, F. \& John, P. (2010). Explaining Internet Banking Behavior: Theory of Reasoned Action,Theory of Planned Behavior, or Technology Acceptance Model? Journalof Applied Social Psychology, 40(5), 1172-1202.

Zahid, N., Mujtaba, A. \& Riaz, A. (2010). Consumer Acceptance of On line Banking. European Journal of Economics, Finance and Administrative Sciences, 27(3). 